\title{
ECOLOGY
}

\section{АДМІНІСТРАТИВНО-ТЕРИТОРІАЛЬНЕ РАЙОНУВАННЯ ТА ОСОБЛИВОСТІ СТРУКТУРИ ПІВДЕННО-БУЗЬКОГО ЕКОКОРИДОРУ}

\author{
Совгіра C. В., д. п. н., професор \\ Гончаренко Г. $\boldsymbol{\epsilon}$., к. б. н., дочент
}

Украӥна, Умань, Уманський державний педагогічний університет імені Павла Тичини

DOI: https://doi.org/ 10.31435/rsglobal_ws/30112018/6231

\section{ARTICLE INFO}

Received: 15 September 2018

Accepted: 22 November 2018

Published: 30 November 2018

\section{KEYWORDS}

structure ecocorridor,

Southern Bug ecological corridor, regional specifics, administrative-territorial zoning.

\begin{abstract}
The article reveals the structure of the Southern Bug ecological corridor. It is established that it is solid, it occupies the course of the Southern Bug, the floodplain and floodplain terraces of its river valley, partly sloping terrain. The administrative-territorial division of the Southern Bug ecocorridor was carried out. According to the regional specifics, its territory is structured into 8 plots. The upper part (Upper Pobuzhzhia) includes 1-3 plots - from village Holodets (leakage) to the mouth of the river Desna, medium (Average Pobuzhzhia) - 4-6 plots - from the mouth of the river Desna to the city of Pervomaisk (the confluence of the river Sinyukhi in the South Bug river), the lower (Lower Pobuzhya) - $7-8$ sites - from the city of Pervomaysk to the lower reaches of the Nikolaev city. It was established that each site is characterized by considerable mosaic and heterogeneity of natural conditions and landscape complexes. It is proved that South-Bug ecocorridor combines elements of regional ecological networks of Vinnytsia, Khmelnytsky, Kirovograd, Cherkasy, Odesa and Mykolaiv regions.
\end{abstract}

\footnotetext{
Citation: Совгіра С. В., Гончаренко Г. Є. (2018) Administratyvno-Terytorialne Raionuvannia ta Osoblyvosti Struktury Pivdenno-Buzkoho Ekokorydoru. World Science. 11(39). doi: 10.31435/rsglobal_ws/30112018/6231
}

Copyright: (C) 2018 Совгіра С. В., Гончаренко Г. С. This is an open-access article distributed under the terms of the Creative Commons Attribution License (CC BY). The use, distribution or reproduction in other forums is permitted, provided the original author(s) or licensor are credited and that the original publication in this journal is cited, in accordance with accepted academic practice. No use, distribution or reproduction is permitted which does not comply with these terms.

Вступ. У політиці створення і оптимального функціонування природоохоронних територій знаходить відображення політика заповідної справи, зміст якої полягає у створенні середовища, сприятливого для забезпечення життєдіяльності людини, тваринного світу, відтворення земельних і водних ресурсів, охорони, використання та відтворення ресурсів рослинного світу, збереження біорізноманіття і ландшафтів. Це, перш за все, оптимізація відносин у системі природа-суспільство. Тому не випадково, формуючи концепцію сталого розвитку територій, посилену увагу акцентовано на одному з інструментів досягнення цієї умови - розвитку заповідної справи, що являє собою «теорію і практику збереження та відновлення природних комплексів і їх компонентів, а також їх раціонального використання у межах територій та об’єктів природно-заповідного фонду» [3, с. 9].

Ідею створення Всеєвропейської екологічної мережі (European Ecological Network або EKONET) як системи взаємно поєднаних, цінних з екологічної точки зору природних територій, запропоновано групою голландських дослідників у 1993 р. на Міжнародній 
конференції «Охорона природної спадщини Європи через створення Європейської екологічної мережі» (м. Маастріхт, Нідерланди).

Офіційне формування екологічної мережі на території України розпочато після набуття чинності Закону України від 21 вересня 2000 р. «Про затвердження Загальнодержавної програми формування національної екологічної мережі України на 2000-2015 рр.». Основним каркасом екомережі $є$ існуюча мережа природно-заповідних територій та об'єктів, але система екологічної мережі доповнюється новими елементами: землями водного фонду, водноболотними угіддями, водоохоронними зонами, землями лісового фонду, полезахисними лісовими смугами та іншими захисними насадженнями, які невіднесені до земель лісового фонду, землями оздоровчого призначення з їх природними ресурсами тощо [11, ст. 5].

Загальнодержавна програма формування національної екологічної мережі України на 2000-2015 роки передбачає виділення ключових районів, екологічних коридорів, відновлювальних і буферних територій з урахуванням біогеографічних зон; відбір збережених екосистем i ландшафтів, типів середовищ існування видів (екотонів) регіонального i національного значення.

Вагомий внесок у розробку теоретичних і прикладних завдань розбудови національної екомережі на етапі сталого розвитку, розвитку заповідних територій у різні періоди внесли Т. Андрієнко, О. Божко, В. Брусака, В. Борейко, М. Голубець, А. Гудзевич, П. Гриник, В. Гриневецький, М. Гродзинський, В. Давидюк, Я. Дідух, А. Данилюк, О. Деркач, Г. Денисик, Ю. Зінько, І. Ковальчук, Я. Кравчук, В. Костюшин, О. Кагало, О. Маринич, Г. Марушевський, В. Мельничук, Я. Мовчан, С. Мішенін, Л. Патрушева, В. Пащенко, С. Попович, Н. Реймерс, Л. Руденко, С. Стойко, Н. Стеценко, С. Таращук, П. Царик, А. Черемнова, В. Шевченко, Ю. Шеляг-Сосонко, В. Шевчук та інші. Вчені дослідили тісну взаємозалежність між станом природного довкілля та соціально-економічним розвитком суспільства. Вони вважають, що розвиток заповідної справи в Україні значною мірою зумовлюється денатуралізацією природних екологічних систем, яка дедалі посилюється у глобальному та регіональному масштабі. У зв'язку з цим особливого значення набуває підтримання природного ходу основних екологічних процесів, збереження унікальних та типових екологічних систем, всього різноманіття генетичних ресурсів біосфери, які нині перебувають під загрозою знищення через надмірну експлуатацію природних ресурсів та деструкцію ландшафтів [13, с.378].

В рамках нашого дослідження Південно-Бузький меридіональний екологічний коридор розглядав В. Костюшин. Автор здійснив стислий огляд біорізноманіття басейну р. Південний Буг та даних щодо найцінніших територій, які збереглися у долині річки та поряд 3 нею, зібрав матеріал, який $\epsilon$ першим кроком до розробки детальної схеми Південно-Бузького екологічного коридору та його практичного створення [9].

С. Смельяновою проведено оцінку ефективності функціонування та просторової структури екомережі долини річки Південний Буг. Встановлено, що за всіма параметрами екомережа долини річки Південний Буг відзначається досить високою зв'язаністю завдяки коротким міграційним шляхам між довільно взятими ключовими територіями, а також їхнім залученням до складу циклів, що $є$ оптимальним для розподілення міграційних потоків, зокрема альтернативних. Автором встановлено, що в екомережі долини річки Південний Буг центральними є Буго-Деснянська, Середньобузька, Вінницька та Вороновицька ключові території, які відзначаються високим ступенем біологічного та ландшафтного різноманіття, великою кількістю функціонуючих об'єктів природно-заповідного фонду [2, с.17].

Проблеми й перспективи Південно-Бузького екокоридору в умовах міста Вінниці вивчав А. Гудзевич. Автор відзначив проблемність функціонування Південно-Бузького екокоридору в умовах міського середовища. Науковець довів, що для забезпечення цілісності Південно-Бузького екокоридору необхідно формувати паралельні екокоридори по водоохоронних зонах приток Південного Бугу, оскільки практично всі малі річки-притоки Південного Бугу у Вінниці більшою чи меншою мірою можуть виконувати функції екокоридорів у міській екомережі, зв'язуючи Південно-Бузький екокоридор 3 навколишніми лісовими масивами чи внутрішньоміськими екоцентрами за умови їх оптимізації, а подекуди i шляхом встановлення охоронного режиму [1].

Функціонально-просторові особливості збалансованого природокористування в межах Бузького екокоридору досліджували О. Мудрак, Г. Мудрак, С. Кушнір. Науковці за особливостями структури землекористування поділили долину Південного Бугу на декілька відтинків. Перший - найвища частина Центрального Поділля $\epsilon$ вододілом між басейнами Горині і Дністра. Ділянка почленована притоками Південного Бугу на широкі, зрідка хвилясті 
смуги. Територія має щільну яружно-балкову мережу, яри заліснені. Другий відтинок річкової долини характеризується оптимальнішою структурою землекористування, домінантне положення в якій займають дубово-грабові лісові масиви з фрагментами прибережно-водної рослинності в комплексі з болотами і луками. На цій території чимало ставків, створених при загачені річок, та інших штучних водойм (найбільше з них - Летичівське водосховище). Третій відтинок вирізняється особливою природною рослинністю «поліського типу». Четвертий відтинок долини Південного Бугу є значно повноводніший, де зростає глибина урізу річкової долини, ширина іiі коливається від 100 м до 3 км (в межах Ладижинського водосховища). П'ятий відтинок долини Південного Бугу характеризується значним антропогенним перетворенням ландшафтів, які представлені лесовими височинами, сильно почленованими ярами й балками, врізаними в кристалічні породи, з чорноземами типовими малогумусними та опідзоленими, грабовими дібровами. Науковці дослідили, що особливу цінність у межах Бузького екокоридору становить ландшафтно-ценотичне і видове різноманіття таких природних ядер: «Центральнобузьке» (ключова територія національного рівня) у складі НПП «Верхнє Побужжя»; «Сандрацько-Березнянське» (ключова територія регіонального рівня) в складі зоологічного заказника місцевого значення «Сандрацький» $\mathrm{i}$ заповідного урочища «Березнянський ліс»; «Подільсько-Поліське» в складі перспективного НПП «Подільське Полісся»; «Буго-Деснянське» у складі зоологічного заказника загальнодержавного значення «Буго-Деснянський»; «Середньобузьке» у складі РЛП «Середнє Побужжя» і «Немирівське Побужжя»; «Мазуровецьке» (ключова територія локального рівня) в складі заказників місцевого значення «Мазуровецька дубина» (орнітологічного), «Прибузький» (ландшафтного); «Самчинецьке» у складі ландшафтного заказника «Урочище «Самчинецьке»; «Буго-Собське»у складі перспективного РЛП «Буго-Собський»; «Крушинівське» у складі ботанічних заказників місцевого значення «Крушинівський» і «Сумівський»; «Устянське» у складі ботанічного заказника державного значення «Урочище «Устянська дача» [7, с. 25].

Екомережу Бузького природного коридору вивчали К. Полянська та М. Богомаз. Дослідники запропонували виділяти суцільну буферну зону навколо екокоридору вздовж річки Західний Буг, мінімальна ширина якої в разі, якщо сільськогосподарські угіддя підходять до урізу води й екокоридор різко звужується, відповідає параметрам прибережних захисних смуг для великої річки, прописаним у Водному кодексі України - 100 метрів, при крутизні схилів більше 3 градусів - 200 метрів, де встановлюється режим обмеженої господарської діяльності, забороняється: 1) розорювання земель (крім підготовки грунту під заліснення і залуження), садівництво і городництво; 2) застосування і зберігання мінеральних добрив і пестицидів; 3 ) організація літніх таборів для утримання худоби (ВРX, свиней, овець, коней, курей тощо); 4) будівництво будь-яких споруд (особливо дач, кемпінгів, баз відпочинку, санаторіїв тощо), крім гідротехнічних і лінійних споруд; 5) миття й обслуговування транспортних засобів; 6) організація звалищ, гноєсховищ, розміщення кладовищ, скотомогильників, полів фільтрації, накопичувачів рідких i твердих промислових, побутових, органічних відходів. Якщо екокоридор включає прибережну захисну смугу, тобто його ширина більша за 100-200 метрів, пропонується виділяти навколо нього суцільну буферну зону з мінімальною шириною 100 метрів. Навколо територій та об'єктів ПЗФ для забезпечення необхідного режиму охорони природних комплексів та об’єктів, запобігання негативному впливу господарської діяльності запропоновано встановлення охоронної зони [10].

Проведені дослідження вищезазначених науковців здійснили певний внесок у розбудову екомережі України, іiі структурування. Але незважаючи на широкі дослідження означеної проблеми багато аспектів залишилися поза увагою науковців. Набувають актуальності питання систематизації регіональних екомереж та перспективних заповідних територій Південно-Бузького меридіонального екологічного коридору, зокрема здійснення його характеристики за адміністративно-територіальним районуванням.

Мета. Схарактеризувати Південно-Бузький екокоридор за принципом адміністративнотериторіального районування із особливостей його структури.

Результати дослідження. Просторова структура Південно-Бузького екокоридору зумовлена природними (положенням природних ядер, гідрологічною мережею областей, наявністю великих лісових масивів тощо), соціальними умовами (урбанізаційними процесами, рівнем гемеробії біогеоценозів та ін.) та приурочена до басейну річки Південний Буг.

Південний Буг бере початок поблизу с. Холодець Волочиського району в західній частині Хмельниччини, на Верхньобузькій (Авратинській) височині, далі річка тече на південний схід, перетинає Вінниччину, Кіровоградщину (межує з Одеською та Миколаївською 
областями) і на території Миколаївської та Херсонської областей впадає в Бузький лиман Чорного моря, який є відгалуженням Дніпровського лиману.

Річка тече майже прямолінійно на схід-південний схід. Більша частина річки протікає лісостеповою зоною. Довжина річки 806 км. Річний стік в гирлі становить 3,39 км² [5, с.7].

Південний Буг зазвичай поділяють на три ділянки: верхню течію - від витоків до м. Вінниці, середню - від м. Вінниця до с. Олександрівки та нижню течію - від с. Олександрівка до гирла (м. Миколаїв).

У верхній течії (Верхнє Побужжя) річка тече заболоченою долиною з урізом до 1,5 км, схили їі пологі, подекуди заліснені.

Для аналізу регіонального розподілу ПЗФ існують приклади застосування поділу території згідно з басейновим принципом, біогеографічними особливостями, поширенням ландшафтів та фізико-географічним районуванням.

Поділ Південно-Бузького екокоридору за адміністративним районуванням подано на рис. 1.

\section{Хмельницька обл. \\ 1 - Волочиський р-н \\ 2 - Красилівський р-н \\ 3 - Хмельницький р-н \\ 4 - Старокостянтинівський р-н \\ 5 - Старосинявський р-н \\ 6 - Летичівський р-н \\ 7 - Деражнянський р-н \\ 8 - Ярмолинецький р-н}

9 - Хмільницький р-н

10 - Калинівський р-н

11 - Літинський р-н

12 - Жмеринський р-н

13 - Вінницький р-н

14 - Липовецький р-н

15 - Тиврівський р-н

16 - Шаргородський р-н

17 - Немирівський р-н

18 - Тульчинський $\mathrm{p}-\mathrm{H}$

19 - Томашпільський $\mathrm{p}-\mathrm{H}$

20 - Іллінецький р-н

21 - Гайсинський р-н

22 - Тростянецький р-н

23 - Крижопільський р-н

\section{4 - Теплицький р-н}

25 - Бершадський р-н

26 - Чечельницький р-н

\section{Черкаська обл. 27 - Христинівський р-н 28 - Уманський р-н}

Кіровоградська обл. 29 - Гайворонський р-н 30 - Благовіщенський р-н 31 - Голованівський р-н 32 - Вільшанський р-н

Одеська обл. 33 - Балтський р-н 34 - Савранський р-н 35 - Любашівський р-н

\section{Миколаївська обл 36 - Кривоозерський р-н 37 - Первомайський р-н 38 - Врадіївський р-н}

39 - Арбузинський р-н 40 - Доманівський р-н 41 - Братський р-н 42 - Єланецький р-н 43 - Вознесенський р-н 44 - Веселинівський р-н 45 - Новоодеський р-н 46 - Миколаївський р-н 47 - Вітовський р-н 48 - Очаківський р-н

Рис. 1. Поділ Південно-Бузького екокоридору за адміністративним районуванням

Верхня частина екокоридору (Верхнє Побужжя) включає 1-3 ділянки - від с. Холодець (витік) до гирла р. Десна.

Перша ділянка - від с. Холодець (витік) до місця впадіння у неї р. Бужок (смт. Меджибіж Летичівського району). Ця ділянка у рельєфі являє собою плато з абсолютними висотами 300-320 м, піднімаючись у багатьох місцях до 360-380 м. Ця найвища частина Центрального Поділля $є$ вододілом між басейнами Горині і Дністра [6, с.24].

По території Хмельницької області Південно-Бузький екокоридор проходить долиною річки Південний Буг, яка бере початок на Подільській височині, прямує в південно-східному напрямку між Подільською та Придніпровською височинами. Довжина екокоридору Південного Бугу становить 806 км, в межах Хмельницької області - 140 км. 
Друга ділянка верхньої частини (Верхнє Побужжя) екокоридору - від гирла р. Бужок до м. Хмільник - характеризується оптимальнішою структурою землекористування. На цій території чимало ставків, створених при загачені річок та інших штучних водойм (найбільше 3 них - Летичівське водосховище) [6, с.24].

Третя ділянка верхньої частини (Верхнє Побужжя) екокоридору - від м. Хмільник до гирла р. Десна. Вирізняється особливою природною рослинністю «поліського типу». Лівобережна частина ділянки екокоридору представлена ландшафтами лесових денудаційних височин з чорноземами типовими малогумусними, сірими лісовими грунтами, 3 дубовограбовими дібровами, лучними степами [6, с.24].

Принцип адміністративного поділу грунтується на комплексі соціально-історичних передумов, у якому досить важко простежити природні першопричини. Формування ПЗФ базується на об'єктивних природних закономірностях, які визначають відмінність окремих територій та створюють природне різноманіття [4, с.66].

У середній течії (Середнє Побужжя) річка перетинає Український кристалічний щит, по території Вінниччини долає 352 км. Середня частина екокоридору (Середнє Побужжя) Південно-Бузького екологічного коридору включає 4-6 ділянки - від гирла р. Десна до м. Первомайськ (місце впадіння р. Синюха в р. Південний Буг).

Четверта ділянка середньої частини Південно-Бузького екокоридору простягається від гирла р. Десна до гирла р. Соб. Південний Буг на території Вінницької області має довжину 352 км [14, с.45].

На цій території він значно повноводніший, де збільшується глибина урізу річкової долини, ширина іiї коливається від 100 м до 3 км (в межах Ладижинського водосховища). Вона вирізняється особливою мальовничістю другого і третього каскаду порогів природного походження - унікальних місць, яких ніде більше немає на теренах Центральної і Східної Європи. Висота крутих схилів 20-30, інколи -80 м, а загальний уріз долини досягає 180 м. Поблизу Вінниці знаходиться значний масив плейстоценових піщаних відкладів. На цій ділянці річка має пороги. Вони часто утворюють каскади 3 3-5 окремих частин та простягаються на відстань 1-3 км. На порожнистих ділянках нахил русла 1-3, швидкість течії 3-4 м/с. Пороги Побужжя частково знищені, особливо спорудженням гідротехнічних споруд смт. Тиврів [8].

П’ята ділянка другої частини (Середнє Побужжя) Південно-Бузького екокоридору - від гирла р. Соб до м. Гайворон (Кіровоградська область) - характеризується значним антропогенним перетворенням ландшафтів, які представлені лесовими височинами, сильно почленованими ярами й балками, врізаними в кристалічні породи, 3 чорноземами типовими малогумусними та опідзоленими, грабовими дібровами $[7$, с.25]. Ширина річкової долини коливається в межах 100-500 м, береги невисокі. Залісненість річкової долини фрагментарна [8]. В нижній течії схили долини Південного Бугу мають мальовничі ділянки, цінні лісорослинні угруповання, древні геологічні відшарування, джерела грунтових вод, вікові і екзотичні деревні породи [12].

Нижня частина Південно-Бузького екокоридору (Нижнє Побужжя) включає 7-8 ділянки - від м. Первомайськ до пониззя м. Миколаїв.

Сьома ділянка долини Південного Бугу - від м. Первомайськ до м. Вознесенськ. У пригирловій частині нижче м. Первомайська річка Південний Буг переходить від Придніпровської височини до Причорноморської низовини і вигляд ії долини різко змінюється. Вона поступово звужується (до 200-300 м) і зростає висота гранітних берегів і нахил русла. Подолавши виходи кристалічних порід Українського щита (нижче за течією села Олександрівка) зменшується нахил русла річки і висота берегів, а ширина долини зростає до 3 3,5 км і місцями 3'являється заплава. Південний Буг тече по широкій долині 3 низькими берегами, розмиваючи піски і вапняки. В даний час уздовж берегів насипані дамби, завдяки яким заплавні ділянки ріки не заливаються водами під час весняних паводків.

Восьма ділянка нижньої частини Південно-Бузького екокоридору (Нижнє Побужжя) простягається від м. Вознесенськ до пониззя м. Миколаїв. Гирлова частина починається у м. Нова Одеса і до м. Миколаєва, де приймає правий, найбільш великий приплив - р. Інгул, Південний Буг тече по рівнинній місцевості. У м. Миколаєва русло річки розширюється, утворюючи Бузький лиман. Далі протікає поблизу розкопок стародавнього міста Ольвія і впадає Дніпровський лиман.

Висновки. За особливостями структури Південно-Бузький меридіональний екологічний коридор поділяється на декілька ділянок, відповідно до поділу річки Південний Буг на три ділянки: верхню частину (верхня течія - від витоків до м. Вінниці), середню (середня течія - 
від м. Вінниця до с. Олександрівки) та нижню (нижня течія - від с. Олександрівка до пониззя м. Миколаїв). Відповідно до регіональної специфіки структуровано територію ПівденноБузького екокоридору на 8 ділянок. Верхня частина (Верхнє Побужжя) включає 1-3 ділянки від с. Холодець (витік) до гирла р. Десна, середня (Середнє Побужжя) - 4-6 ділянки - від гирла p. Десна до м. Первомайськ (місце впадіння р. Синюхи в р. Південний Буг), нижня (Нижнє Побужжя) - 7-8 ділянки - від м. Первомайськ до пониззя м. Миколаїв).

\section{ЛІТЕРАТУРА}

1. Гудзевич А. В. Проблеми й перспективи Південнобузького екокоридору в умовах міста Вінниці. Наукові записки Вінницького державного педагогічного університету імені Михайла Кочюбинського. Серія: Географія. 2014. Вип. 26. С. 12-16.

2. Ємельянова С. М. Вища водна та болотна рослинність долини р. Південний Буг (синтаксономія, антропогенна динаміка, охорона): автореф. дис. ... канд. біол. наук. Київ, 2015. 22 с.

3. Заповідна справа в Україні: навч. посіб. / за ред. М. Д. Гродзинського, М. П. Стеценка. Київ: Географіка, 2003. $306 \mathrm{c}$.

4. Іваненко Є. І. Аналіз розміщення природно-заповідного фонду України: підхід, стан, проблеми. Украӥнський географічний журнал. 2013. № 3. С. 64-69.

5. Костюшин В., Куземко А., Онищенко В. та ін. Південно-Бузький меридіональний екологічний коридор: стислий огляд біорізноманіття та найцінніші території. Київ: Wetlands International Black Sea Programme, 2007. 92 c.

6. Любчак О. О. Чарівне Поділля: Краєзнавчі нариси. Одеса: Маяк, 1990. 88 с.

7. Мудрак О. В., Мудрак Г. В., Кушнір С. Л. Функціонально-просторові особливості збалансованого природокористування в межах Бузького екокоридору. Збалансоване природокористування. 2014. № 1. C. $20-27$.

8. Natural conditions and structure of the Southern Buh meridional ecological corridor: collective monograph / S. Sovhira, H. Honcharenko, V. Artamonov, O. Mitriasova. Palmarium Academic Publishing,2018. 233 p.

9. Південно-Бузький меридіональний екологічний коридор: стислий огляд біорізноманіття та найцінніші території / за ред. В. Костюшина. Київ, 2007. 69 с.

10. Полянська К. В., Богомаз М. В. Екомережа Бузького природного коридору: виділення буферних зон вздовж річки Західний Буг. Екологія водно-болотних угідь i торфовищ: зб. наук. ст. / за ред. В. В. Коніщука. Київ: ТОВ «НВП «Інтерсервіс», 2014. С. 192-194.

11. Про Загальнодержавну програму формування національної екологічної мережі України на 2000 2015 роки: Закон України від 21.09.2000 p. № 1989-III. Дата оновлення: 10.06.2012. URL: http://zakon2.rada.gov.ua/laws/show/1989-14 (дата звернення: 11.04.2018).

12. Систематизація регіональних екомереж та перспективних заповідних територій Південно-Бузького меридіонального екологічного коридору: колективна монографія / С. Совгіра, Г. Гончаренко, В. Миколайко, Н. Душечкіна. Умань, Видавець “Сочінський М. М.”, 2018. 478 с.

13. Черемнова А. І. До питання створення та охорони територій та об’єктів природно-заповідного фонду України. Актуальні проблеми держави і права. 2005. Вип. 25. С. 378-382.

14. Яцентюк Ю. В. Екомережа Вінницької області. Вінниця: Едельвейс і К, 2011. 128 с. 